\title{
Adaptations and inventions in the praxis of nurses in home care: implications of the reflective practice ${ }^{a}$
}

\author{
Adaptações e invençōes na práxis da enfermeira na atenção domiciliar: implicações da prática \\ reflexiva
}

\section{Adaptaciones e invenciones en la praxis de la enfermera en la atención domiciliaria: implicaciones de la práctica reflexiva}

\section{Angélica Mônica Andrade ${ }^{1,2}$ (1) Kênia Lara Silva ${ }^{2}$ (1)}

1. Universidade Federal do Rio de Janeiro. Macaé, RJ, Brasil.

2. Universidade Federal de Minas Gerais. Belo Horizonte, MG, Brasil.
Corresponding author:

Kênia Lara Silva.

E-mail: kenialara17@gmail.com

Submitted on $01 / 03 / 2018$.

Accepted on 05/05/2018.

DOI: 10.1590/2177-9465-EAN-2017-0436

\begin{abstract}
Objective: To analyze the praxis of nurses at home, considering their power to invent new ways of producing care. Methods: This is a Unique Case Study, with a qualitative nature, anchored in the theoretical-methodological framework of dialectics. It was attended by 13 nurses working in home care services in Minas Gerais State. Data were obtained through participant observation and interview, and then submitted to Critical Discourse Analysis. Results: The praxis of the nurse at home is shaped by the relationship of interdependence between theory and practice and of a practice built through adaptations and inventions entailed by the specific context of Home Care, as well as by the space where care happens. Conclusions and implications for practice: Adaptations and inventions represent the sensible action of nurses expressed during practice, with a view to transforming a reality. Moreover, they have a dialectical relationship between lack of resource and accomplishment of care.
\end{abstract}

Keywords: Home Care Services; Nurse's Role; Nursing Care; Nursing.

\section{Resumo}

Objetivo: Analisar a práxis de enfermeiros no contexto domiciliar, considerando seu potencial de invenção de novas maneiras de produção do cuidado. Métodos: Estudo de Caso Único, de natureza qualitativa, ancorado no referencial teórico-metodológico da dialética. Participaram 13 enfermeiras que atuam em serviços de Atenção Domiciliar em Minas Gerais. Os dados foram obtidos pela observação participante e entrevista, e submetidos à Análise de Discurso Crítica. Resultados: A práxis da enfermeira no domicílio é configurada pela relação de interdependência entre teoria e prática e de uma prática construída por meio de adaptações e invenções que acontecem disparadas pelo contexto próprio da AD, bem como pelo espaço em que o cuidado acontece. Conclusões e implicações para a prática: As adaptações e invenções representam a ação consciente das enfermeiras que se manifesta durante a prática visando transformar uma realidade. Também possuem uma relação dialética entre a insuficiência de recurso e a realização do cuidado.

Palavras-chave: Serviços de Assistência Domiciliar; Papel do Profissional de Enfermagem; Cuidados de Enfermagem; Enfermagem.

\section{Resumen}

Objetivo: Analizar la práctica de enfermería domiciliaria considerando su potencial de implementar nuevas formas de producción del cuidado. Métodos: Estudio de caso único, de naturaleza cualitativa, fundamentado por el marco teórico-metodológico de la dialéctica. Participaron 13 enfermeras que se desempeñaban en los servicios de atención domiciliaria en Minas Gerais. Los datos fueron obtenidos mediante observación participante y entrevista, siendo sometidos a Análisis de Discurso Crítico. Resultados: La práctica domiciliaria de enfermería se configura por la relación de interdependencia entre teoría y práctica y de una práctica construida mediante adaptaciones y nuevas prácticas desencadenadas por el contexto propio de la atención domiciliaria, así como por el espacio en el cual se brinda la atención. Conclusiones e implicaciones para la práctica: Las adaptaciones y nuevas prácticas representan la acción consciente de enfermería que surge durante la práctica para transformar una realidad. Además, se presenta una relación dialéctica entre insuficiencia de recursos y realización del cuidado.

Palabras clave: Servicios de Atención de Salud a Domicilio; Rol de la Enfermera; Atención de Enfermería; Enfermería. 


\section{INTRODUCTION}

Home Care represents a growing health care modality worldwide, conducive to the implementation of new care production settings. ${ }^{1-4}$ The establishment of the Program "Melhor em Casa - A Segurança do Hospital no Conforto do seu Lar", by the Federal Government of Brazil portrays a search for expansion of Home Care teams and aims to provide home care in order to expand the problem-solving and comprehensiveness of care nationwide. ${ }^{2,4}$ Home Care has the potential to provide assistance to the users' demands and needs, and innovative and unique care in health. ${ }^{3,4}$

In these services, nurses are important in the care either in the management of services or in direct care. ${ }^{4,5}$ The duties of these professionals are essential for the management of the home care plan, as well as for the bond it establishes with users and their families. ${ }^{4,5}$

It is worth noting that the work of nurses in Home Care involves a technological innovation, especially in the field of soft technologies. ${ }^{1,4}$ In their practice, it is necessary to "mobilize different areas of knowledge and elements of innovation" in their practice. .:216 $^{2}$

It should be noted that home-based care "has its own characteristics".6:494 Thus, "home context must be perceived through a comprehensive perspective that goes beyond physical space, which considers this environment as a set of things, events and human beings" interconnected with each other, "whose entities represent a particular, interfering and simultaneous character". 6:494 For the home care, the nurse must be able to act in different situations, needing to unite the diverse knowledge of the profession. ${ }^{6,7}$

This type of care "is characterized by a complex practice that requires health professionals prepared for care in people's home".8:7749 In spite of the need for a training that contemplates the singularities of home care, studies indicate the invisibility of Home Care context in the nurse's training processes. ${ }^{4,8,9}$ Even when present, Home Care-related academic training tends to be punctual in face of the complexity of working at home. ${ }^{8}$

As a consequence, we visualize distances between the academic training of nurses and processes required for their performance in the Home Care. The complexity and dynamicity of the home context mobilize in nurses the invention of new ways of producing care through reflective practice and learning, generating implications in their praxis. ${ }^{10}$

Reflective professional practice refers to an activity in which the individual reflects in action and on action, aiming at continuously improving their performance through experiences. ${ }^{11}$ Reflective learning deals with the possibility of the subject reflecting on their own independent action at the time and space in which it occurs. The expectation is that reflection enhances the development of thought and action. The "professional reflects on what and how is learning, in a process of self-organization of own knowledge. It is also capable of distancing itself from action, observing it and delimiting it methodologically, comparing what it knows with other possible knowledge". 10:17

Praxis, in turn, is human action that is modified by interference of consciousness. It is the conception of a new reality from an action of man in a given matter. In this sense, praxis is a junction of theory and practice, which is revealed through the understanding of reality sustained in theoretical reflection. Such a conjunction happens in a dialogical way, since the practical activity is subject to theorizing and, at the same time, the theory is modified according to the requirement of the real. ${ }^{12}$

Therefore, this study aims to analyze the praxis of nurses in the home context, considering their potential to invent new ways of producing care.

\section{METHODS}

It is a qualitative research, in the Single Case Study mode, anchored in the theoretical-methodological framework of the dialectics. ${ }^{13,14}$ The case in question consists of "nurses' performance in high complexity home care", considering that the higher the complexity of care in Home Care the more is the requirement of mobilization of nurses' knowledge. ${ }^{4}$ In order to define the setting of the study, the 22 municipalities that owned Home Care Services linked to the Melhor em Casa Program in Minas Gerais State were considered. The Home Care Services of the municipalities of Uberlândia and Betim were selected, considering the following inclusion criteria: case study, number of nurses working and indication of invasive and/or non-invasive mechanical ventilation.

The research participants were the nurses working in Home Care teams in the chosen settings: twelve and one man. To avoid the identification of these, we chose to standardize the female gender to refer them, totaling 13 nurses as participants in the study.

The production of the empirical material occurred from May to December 2016 and happened in two moments. The first was the peripheral participant observation of the nurses' performance, guided by a guiding script with record in field diary and audio recording. The observation was guided by questions related to the description of the following aspects: Subjects in the setting; Actions performed by the nurse; Tools used in practice; Technologies used in practice; Situations that express challenges at work; and Reporting/Perception of the researcher against the observed. The researcher's entry into the homes was preceded by the authorization of the professionals who conducted the care practices, as well as the users or caregivers.

The observational phase was carried out during the work of nurses in Home Care, mainly in palliative care, death and post-death care visits, discharge, admissions, medication ad- 
ministration, complex dressing, oxygen therapy and mechanical ventilation (including pediatric), paracentesis, assessment and intercurrent care. A total of 272 visits were performed on 186 patients, totaling 266 hours and 30 minutes of observation, and had as a criterion of interruption the condition of response to the research objective. The built field diary resulted in 277 pages of text.

Guided interviews were also conducted through a semistructured script, whose key issues were: How did you learn to act in Home Care? Describe situations that required learning during the time you have been active in Home Care and among these situations that you have reported to me, how have you been conducting situations of uncertainty, complex or for which you were not prepared for? The interviews with the nurses, with audio recording and recording in field notes with impressions of the researcher happened after the accomplishment of the whole observational part, according to the setting. They were individually scheduled and performed a total of 8 hours and 58 minutes of recording time resulting in 169 pages of text after transcription in full. The transcript followed the agreements, models and guidelines proposed for the area. ${ }^{15,16}$

Participants received an identification assigned by an alphanumeric classification composed by the initial letter of the municipality ( $U$ for Uberlândia and $B$ for Betim) and the number of 01 to 09 for Uberlândia and 01 for 04 for Betim, assigned randomly. The production of the data assured the quality aspects of qualitative research, such as: credibility, portability and confirmability. ${ }^{17}$

The analysis of the study was conducted by the interpretation of the categories of analysis Reflexive Learning and Praxis, anchored in the theoretical frameworks of Donald Schön and Sánchez Vázquez. ${ }^{11,12}$ For the analysis of the empirical data, the Critical Discourse Analysis ${ }^{18}$ was performed, to grasp social practice of individuals by the language used in discourses conditioned to historicity, considering the lived reality. ${ }^{18}$ During the analysis of the data, the discursive aspects ${ }^{18,19}$ that emerged were: assessment statements, metaphors, affirmation with deontic modality, metadiscourse and interdiscursivity. In order to construct the results, we analyzed the discursive events, understood as parts of a discursive practice, considering the three-dimensional dimensions of text, discursive practice and social practice in the socio-historical context and social transformations. ${ }^{18}$

The research project that propitiated this study was approved by the Human Research Ethics Committee of the Universidade Federal de Minas Gerais (CAAE: 51528815.0.0000.5149) on $02 / 15 / 2016$ and all the steps of this research were carried out in agreement with the Resolution of the National Health Council (CNS- Conselho Nacional de Saúde) 466/2012. ${ }^{20}$

The presentation of results of the study obeyed the guidelines for reports of qualitative research projects using interviews available in the Consolidated Criteria for Reporting Qualitative Research (COREQ).

\section{RESULTS}

The findings of the study reveal the dichotomized relationship between theory and practice in the context of Home Care. The practice is represented as "more important" and theory as something far from the application in the home context. In the speeches, we note the presence of assessment statements that portray Home Care as a space of care possessing singularities that require adaptations of theory to practice. Such a requirement is evidenced by the discursive element of the deontic modality ("you have to"), which indicates obligation or need for adaptation to the reality of home.

[...] It's because, in fact :: in practice, if you have theory, practice becomes easier. [...] But I think what's more important is practice. (Interview U04)

I think theory is very different, everything I've learned is very different in Home Care. There's a loto fimprovisation, there's a lot of (+) creativity, [...] so, the theory I learned is as if I did not even need it in Home Care. It's totally different. For example, a delayed bladder catheter passage, which in theory you learn to have sterile field, everything right, clamps and such, but sometimes you have to improvise a field with the glove packaging, you know, and there is no sterile wad, sometimes no clamp we have, so, you will have to put your hand with the gauze with the glove and you have to improvise, something like that, so I realize that here is different. [...] (Interview U05)

The discourses express the need for the nurse to be able to adapt theory to practice, through the repeated use of the deontic modality ("has to") reinforced by the metaphorical expression ("jogo de cintura"- (Brazilian expression that means flexibility when handling with things). Thus, there is a need for adaptation, observed by the use of discursive metaphor ("a lot of kludge").

There has to be a lot of flexibility to contribute to my practice, and I have improved a lot in Home Care precisely because of it, because of creativity, improvisation, flexibility. [...] but the difference between theory and practice is:: as I said the sensitivity, the creativity she has to be with the nurse to do carry out some procedure at home (Interview U09)

[...] there is something else that we deal with a lot in Home Care that is the improvisation, you have to know how to improvise, how to deal with the difficulty sometimes because of a missing material needed, or even an environment that does not favor a technique that you need to do, people you need to have this flexibility to deal with it. [...] we have to do what we have to do, anyway. (Interview B02) 
[...] But when you get inside a patient's home [...] You have to do a lot of kludge. [...] sometimes you have to adapt yourself, because you cannot use $100 \%$ of the theory, the asepsis techniques (laughs) are exceptions, because in the excellent case it has no conditions, it is:: you enter inside houses that are very clean, good houses, but sometimes you enter inside a house that hygiene is precarious because the family has no condition to tidy it up, to clean, to buy a soap, a toilet soap, a disinfectant, does not have, so, the theory is good, but you have to have flexibility for you to try to apply the maximum of theory within the practice, within a residential environment that is different from a hospital environment. (Interview B04)

The meaning of importance for the need and obligation to adapt at home is present in the speeches. The normative and literary interdiscourses ("you will be able to continue with your technique, be it sterile or just clean", "there are ordinances from the Ministry of Health") impose a content of recommendation to the discourse that, in practice, operates adapting to reality. However, it is highlighted the attempt not to trivialize the relevance of scientific evidence to practice by means of the metadiscursive resource ("But we cannot despise what is right, and what one learns in theory"; "we adapt, but it is universal"; "SO, not that we perform the wrong procedure at home").

The use of metadiscourse can be evidenced by evasive expressions, such as "but" and "so", and indicates an attempt to control discourse and also a dialectical relation between discourse and subjectivity. Given this, the participants are positioned and constitute the discourse. Otherwise, they engage in practice that refutes and reshapes the orders of discourse that position them.

[...] And that's when you're going to see what you're going to adapt that will work for the patient, which will not cause any harm to him, and that you'll be able to continue with your technique, be it sterile or just clean. (Interview U04)

Then, but::: the ::: ESSENCE of theory, that, I [...] know that tracheostomy tube replacement is also sterile, so that's it, there are things that do not change, but we adapt. Then the service teaches you that. [...] is::: ADAPTATION. Home service I think is basically adaptation. But we cannot despise:: what is right, and what we learn in theory, right?. [...] We adapt, but it is universal. I :: particularly, I suffered a little because:: (+) I was wondering, "Am I doing right?". [...] So it gets a bit frustrated at first, I was a little frustrated and I thought: Am I doing right or wrong? (Interview U06)

[...] SO, not that we perform the wrong procedure at home, [...] have the Ministry of Health, which BASE people in our practice at home. But [...] not every home will have a perfect lightning, not every home will have an armrest to puncture, [...] so, it's very different from theory to practice. Although we are already based, with protocols and not making the wrong indication, but there won't be asepsis of this type of procedure, I will not have a serum support, so the practice is very different from the theory, very different from theory. [...] So, just for this you have to see that the theory that we learn is totally different from what we apply, it is clear that our practice is based on evidence in clear scientific production, but focused on Home Care, which is new for us to apply in practice, but it is totally different. (Interview U09)

The discourses point out that the ideal result (the purpose) in Home Care is to perform a care action that meets the scientific demands and that, through the adequacy carried out intentionally and consciously, the real result is the best care taken without harming the patient, through adaptations, as shown in Figure 1.

Figure 1. Relationship between theory and practice in the nurse's role in Home Care. Source: Created by the authors. ${ }^{12}$

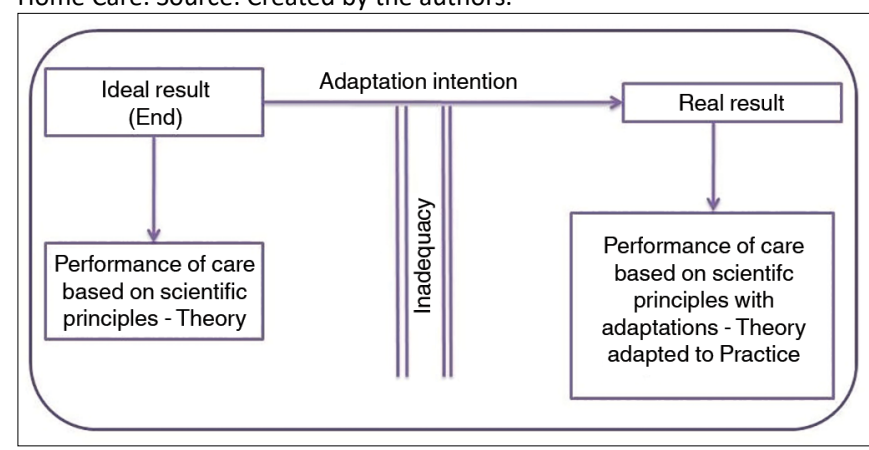

The results also indicate that work at home has particularities that require adaptations, also called "adaptation" or "improvisation" by the participants, occurring in different ways and at different times.

Look, we improvise a lot, but depending on the environmental condition, material, sometimes you need to place a serum properly, the medicine has nowhere to be hanged so this kind of improvisation we are master in it [...] (Interview B01)

The nurse squats to try to puncture. [...] In the car, the nurse reports: "Did you see the conditions that we have to do it? You have to improvise everything". (Field Diary - 24/06/2016 - V111 - U07)

[...] Something like this, so we have to learn to improvise, right. That's what we do a lot. [...] only improvisation [...] (Interview U08) 
It is emphasized, by the expressions "we are master in it", "You have to improvise everything", "That's what we do a lot", "only improvisation" that the action built in Home Care presents recurrence, possessing contextual characteristic. Thus, the adaptations during the practice of the nurse at home are presented in all their performance, evidenced by discursive presuppositions, and this element is an indicator of "truth" already established.

Adaptations are triggered by Home Care's own context, as well as by the space in which care takes place. Therefore, the work environment of the nurse in Home Care requires the professional to seek adaptation.

[...] so, I usually say that in home care who rings the doorbell and asks for permission to enter is us, not in indoors. [...] (Interview U09)

Regarding the adaptation in practice of the nurse in Home Care, there is still a circumstantial component that triggers their need for achievement. It means that, in addition to being related to the proper context of Home Care, the nurses consider that, under certain circumstances, adaptations become necessary.

At "Melhor em Casa" Program we improvise a lot. OMG :: every time, 24 hours a day, I'll give some examples $[. .$.$] , there is no saline support, [...], so we have to spike a$ tape on the wall, you have to make a hook with a clip, [...]l have to take a delay bladder catheter, I have to stroke the other delay bladder catheter in a corner of the glove as sterile field, the technique remains aseptic, but I don't have fenestrated field, I don't have clamps:: we will puncture a patient on our knees, you puncture the patient in a not very comfortable position for you, who is performing the procedure, then it all depends on the creativity of the nurse. Debriding wound also with aseptic technique, of course, but does not have the scalpel handle, so the nurse has to use her creativity [...] I had to puncture the jugular, the patient with a conventional bed, a normal bed at home, there was no way I could puncture the jugular because there was no way I could go behind her bed, so I had to climb on the bed and lay her on my lap and on my knee to puncture the jugular [...] (Interview U09)

So, the kludges are the improvisations, adaptations, you see, almost every day we have to make adaptations, there's no way out! So, we already had several patients that we needed to make these adaptations, sometimes it is a bedridden patient, you have to do a dressing [...] so we start thinking on things. [...] we asked to be able to stick to the wall where the bed headboard was, we put a hook, we pull the rope and we made an adaptation to support his arm for dressing, because he could not hold his arm and sometimes it was difficult someone holding it because it was the whole forearm and hand... the dressing, so we would not be able to do the dressing, so we made those adaptations.[...]. For example, there is a bed, which is not from the hospital, the patient needs to keep the headboard high and, we asked to be able to place either the wood or the block on the base of the headboard to get higher. [...] then, these the kludges, in quotation marks, that we make to help with patient care. (Interview B04)

\section{DISCUSSION}

Theory and practice, as well as their relations, are two ways of behavior of the man face to the reality that establish themselves in close unity. The practical activity that is evidenced in human work refers to an action that seeks to achieve purposes. ${ }^{12}$ In the face of the relations between theory and practice, "praxis is actually a theoretical-practical activity, that is, it has an ideal side, theoretical, and a material side properly practical, with the particularity of being only artificial, by a process of abstraction", can be separated, isolate one from the other. ${ }^{12: 264}$ Thus, it is possible to affirm that praxis is a practical activity associated with conscious activity (theoretical, subjective). From this union, there is a transformation of reality (real, objective).

The results of the study reveal the intentionality of nurses' work by mentioning that they seek to perform their actions in the best way for the patient. In this way, adaptations are carried out consciously, seeking to adapt knowledge from scientific evidence, acquired through academic training or normalized through protocols for the context of Home Care. It is noted that nurses reproduce this dialectical conjugation between theory and practice in a way similar to a relation between right and wrong. In practice, through consciousness, they seek to verify potential errors in the act, in the course of action, making constant adaptations to avoid them.

In this regard, it is humanly common "that, however the actual result is different from the ideal, it is in any case a matter of intentionally fitting the first to the second." This means that the result obtained does not necessarily have to be equal to the ideal model previously elaborated, "adequacy does not have to be perfect". ${ }^{\text {12:222-223 }}$

From the above, it can be affirmed that there are differences between theoretical and practical aspects, in the nurses' role in Home Care, where the primacy of practice is evident. However, considering praxis as an indissoluble theoretical-practical activity, the practical activity of nurses at home is developed in order to reach the end, and the ideal is the result predicted by protocols and books (based on their theoretical knowledge). However, given the demands of the home (environment, physical and instrumental materials) and because of their particularity, 
the activity of consciousness becomes active throughout the practical process, in a constant modification and adaptation of the ideal for the realization of reality. The search for effectiveness of care to provide the best for the patient is revealed continuously, in the action of nurses, in action, permeated by conscious and intentional action.

The discourses reveal the context of the practice in Home Care that must be performed according to the patient's reality. The context of adaptation or adequacy is therefore presented by the peculiar characteristic that home presents, being this a space different from the other health services that does not have a standardized physical structure for the actions of the nurses. In addition, adaptations in the home are presented as a criterion of need or obligation. In view of the contextual context of adequacy, it should be noted that the changes attributed to the ends from which it was set to obtain a more complete access from the subjective to the objective, from the ideal to the real, only certify the indivisibility between the theoretical and the practical in the activity practice. ${ }^{12}$

In order to make home adaptations, nurses use "knowledge as support for their actions because home care requires their knowledge/thinking/acting, since it is necessary to observe, analyze, care and guide to present solution to problems encountered". ${ }^{21: 2}$ The nurses act by reproducing, with mastery, a field of technical and scientific knowledge, human, responsible and sensitive, that dissolves in the act of acting spontaneously, being executed and learned moment by moment. In view of this, the appropriation of the standards of empirical, aesthetic, personal and ethical knowledge in nursing is indicated, being these correlated and interdependent. ${ }^{21,22}$

In the scope of the adaptations and inventions present in the work of nurses in Home Care, empirical and theoretical knowledge is fundamental for the realization of care, but it does not support itself. ${ }^{21}$ The aesthetic standard can be related to the "knowing how" caution. For the action to have an aesthetic quality, it is necessary the unity of ends and means, ${ }^{22}$ being present in the contextual configuration of the adaptations. In Home Care, this knowledge is expressed by the creativity and intuition present in the process of interaction between nurse and patient in the use of household resources to perform procedures, in knowing how to act in relation to individual differences, aiming to create a positive result, as well as empathy in seeking to provide comfort to patients and families. The nature of aesthetic knowledge allows the nurse to act in a way that adapts the situation, according to the means, to achieve a desired result.

It was possible to identify the regularity in the use of the term "improvisation" in the speeches. In the context of reflexive practice, "improvisation consists in varying, combining and recombining" a set of actions within a scheme that gives coherence to action. ${ }^{11: 35} \mathrm{~A}$ problematic situation presents itself as a unique case, a case that "does not is in the manual" and is revealed in many ways at the same time. Thus, the single case exceeds the "categories of existing theory and technique, the professional cannot treat it as an instrumental problem to be solved by applying one of the rules of his stock of professional knowledge." If the professional wants to treat him competently, he must do so by means of "a kind of improvisation, inventing and testing situational strategies that he himself produces". 11:17

The situations considered difficult to carry out at home are understood as the cause of the necessary adjustments in a circumstantial way. Such actions occur when the professional encounters any situation that may be impeding their care. In this sense, the adaptations can be triggered by circumstances that cause surprises to the professional.

By the circumstantial conception of adaptation, Home Care has situations that have revealed themselves as "undetermined zones of practice", which indicate the imprecision, the specificity and the divergence of standards, that avoid the guidelines of technical rationality, that is, of the use of theory and the technique derived from scientific knowledge. ${ }^{11}$

Nurses have a mastery over scientific knowledge and, therefore, affirm that it is necessary to perform (and perform) curative, asepsis and patient positioning techniques, for example. However, knowledge becomes limited in the face of a reality in which one has, for example, only one professional to perform the procedure, the mother who will help the way she succeeds and the patient who has two injuries in the two lower limbs. Given this, the nurse is faced with a different situation than expected, an indeterminate zone of the profession and, through reflection, develops skills that are not commonly explored in professional training. Thus, the solution found escapes from its repertoire constructed by the technical rationality, evidencing a manifestation of the professional artistic talent. ${ }^{11}$

It is added that "when a problematic situation is uncertain, the technical solution of problems depends on the previous construction of a well-defined problem, which is not in itself a technical task". ${ }^{11: 17}$ It is further argued that, when a professional "recognizes a situation as unique, cannot deal with it only by applying techniques derived from his baggage of professional knowledge", and new ways of doing it through professional artistic talent are necessary. "Professional artistic talent" refers to an expression used to refer to "the types of skills that professionals demonstrate in certain situations of practice that is unique, uncertain and conflicting". 11:29

Therefore, professional artistic talent is built by reflective practice developed in different circumstances of professional practice and in which it is necessary to realize what is known and how to know, and then, based on a critical-reflexive analysis, to perfect and reformulate, as well as developing new skills based on what we know how to do and think, being creative in unique situations.

It is relevant to emphasize the use of the metaphorical expression "kludge", identified in the speeches, which involves the idea of "improvisation". Kludge is the necessary procedure 
for the configuration of an improvised artifact. In the health field, improvisation is often associated with unexpected situations or lack of resources. ${ }^{23}$

It should be noted that, in a circumstantial way, the insufficiency of material resources was a determining factor for the accomplishment of adaptations and improvisations according to the participants of this study. The "lack, scarcity, or inadequacy of material resources impels workers, especially those in nursing, to make adaptations to available inputs to ensure that care is provided". ${ }^{24: 685}$

Adaptations and improvisations occur predominantly due to the misuse of health resources, resulting in the precariousness of working conditions. ${ }^{25}$ The lack and/or inadequacy of material resources for work means that the professional "has to use so that adaptations and improvisations can arise". ${ }^{25: 29}$ Contrary to the lack of material resources, adaptations and improvisations often guarantee the follow-up of the assistance and ensure that the work is carried out. ${ }^{26}$ The adaptation and improvisation of objects to care reveal a reflexive work, motivated by the immediate need to produce care, and can be described as responses to the real needs of clinical practice..$^{27}$

In this sense, the practice of adapting/improvising portrays the dialectic present at work, between not having the resource and, at the same time, having to provide assistance. ${ }^{28}$ In this sense, the practice of adapting and improvising interferes with the dynamics of the nurse's work, while at the same time making it possible to carry out the care, can contradictly circumvent prescribed norms, result in the worker's physical and mental time and wear, and may result in iatrogenies in the users served. ${ }^{26,28}$

\section{CONCLUSIONS AND IMPLICATIONS FOR PRACTICE}

The results indicate that the presence of adaptations by the nurses in the home is configured as a response of the conscious action of the professional that manifests itself throughout the practical process in search of transforming a reality. This conception is evidenced as determinant in the face of unpredictability during the practical activity, in which the conscious action seeks to adapt the scientific knowledge (ideal result) to the actual result in the realization of the care.

It should be noted that the adaptations have a dialectical relation with regard to the absence/insufficiency of the resource and, at the same time, the guarantee of the realization of the care. On the one hand, the acts of adapting and improvising allow the recognition of the professional as a person involved in the search of the best for the patient and assure the assistance. On the other hand, they represent the precariousness of working conditions and the absence of a critical attitude in a macropolitical context, they produce uncertainty regarding the execution of scientific principles in the realization of care and can contribute to the perpetuation of such practices in the professional, and it can inhibit changes.
It is believed that the potential for innovation could be more developed if there were adequate materials available and adapted to the home and if, in the training of nurses, the contents necessary for the development of Home Care were specifically worked on. Thus, recognition and appreciation of the innovation present in nurses' work in Home Care is fundamental, in their ability to induce the production of technologies for care.

The social practice is marked by ideologies that mark the actions of nurses in the search to guarantee effective care at home. The use of metaphors and discursive presuppositions indicates the accomplishment of adaptations and improvisations, in a reflexive process in the work. At the same time, such socia practice is inserted in a hegemonic context marked by economic, political, cultural and ideological orientations that express the displacement of responsibility for the microinstitutional scope of nurses' work in contrast to the limitation of specific resources destined to the home space. Faced with the adversities of day-today work, nurses mobilize knowledge in seeking and/or creating better ways of producing care. Thus, the discursive and social practices of the nurses pointed out that they are faced with the need to learn an innovative care, transforming daily and habitual practices of caring so that the care at home is assured.

It should be noted that the methodological approach adopted was adequate to achieve the objective. Regarding the limitation of the study, the participation of 13 nurses stands out. However, such limitation does not invalidate the results of the research, but indicates the need for other studies on the subject. Therefore, it is considered relevant that future researches analyze the particularities of the work developed in the AD in other scenarios, as well as the adaptations and inventions that are necessary. Other methodological approaches are also needed to support evidence-based practice in this setting. It is also necessary to consider the need to build specific knowledge for home care. Such research may contribute to the practice and also to the teaching itself.

\section{Financial support}

We thank the Universidade Federal de Minas Gerais (PRPq/ UFMG), for a financial support of Institutional Program for Qualitative Improvement of the scientific production of UFMG.

\section{REFERENCES}

1. Silva KL, Sena RR, Seixas CT, Feuerwerker LCM, Merhy EE. Atenção domiciliar como mudança do modelo tecnoassistencial. Rev Saúde Pública [Internet]. 2010; 44(1):166-76. Available from: http://www.scielo. $\mathrm{br} / \mathrm{pdf} / \mathrm{rsp} / \mathrm{v} 44 \mathrm{n} 1 / 18 . \mathrm{pdf}$

2. Ministério da Saúde (BR). Portaria № 825, de 25 de abril de 2016 . Redefine a Atenção Domiciliar no âmbito do Sistema Único de Saúde (SUS) e atualiza as equipes habilitadas. Brasília (DF): Ministério da Saúde; 2016.

3. Braga PP, Sena RR, Seixas CT, Castro EAB, Andrade AM, Silva YC Oferta e demanda na atenção domiciliar em saúde. Ciênc Saúde Coletiva [Internet]. 2016;21(3):903-12. Available from: http://www.scielo. br/pdf/csc/v21n3/1413-8123-csc-21-03-0903.pdf 
4. Andrade AM, Silva KL, Seixas CT, Braga PP. Atuação do enfermeiro na atenção domiciliar: uma revisão integrativa da literatura. Rev Bras Enferm [Internet]. 2017 Jan/Feb; [cited 2017 Jun 15]; 70(1):210-9. Available from: http://dx.doi.org/10.1590/0034-7167-2016-0214

5. Stajduhar KI, Funk L, Roberts D, McLeod B, Cloutier-Fisher D, Wilkinson $\mathrm{C}$, et al. Home care nurses' decisions about the need for and amount of service at the end of life. J Adv Nurs [Internet]. 2011 Feb;67(2):276-86. Available from: https://www.ncbi.nlm.nih.gov/pubmed/?term=Home+c are+nurses'+decisions+about+the+need+for+and+amount+of+servic e+at+the+end+of+life

6. Favero L, Mazza VA, Lacerda MR. Experience of a nurse in transpersonal caring for families of neonates discharged from the intensive care unit. Acta Paul Enferm [Internet]. 2012; [cited 2017 Sep 22]; 25(4):490-6. Available from: http://dx.doi.org/10.1590/S010321002012000400002

7. Rodrigues JAP, Lacerda MR, Favero L, Gomes IM, Méier MJ, Wall ML. Modelo de cuidado transpessoal de enfermagem domiciliar de Favero e Lacerda: relato de caso. Rev Gaúcha Enferm [Internet]. 2016 Sep; [cited 2017 Jun 17]; 37(3):e58271. Available from: http://dx.doi. org/10.1590/1983-1447.2016.03.58271

8. Cunha JJ, Lepinski AG, Santo MS, Hermann AP, Bernardino E, Lacerda MR. Contribuições da enfermagem para aprimoramentos no gerenciamento da assistência domiciliar à saúde. Rev Enferm UFPE On Line [Internet]. 2015 May; [cited 2017 Jun 17]; 9(5):7746-52. Available from: file://CC:/Users/susana/Downloads/10520-21821-1-PB.pdf

9. Hermann AP, Lacerda MR, Nascimento JD, Gomes IM, Zatoni DCP. Aprimorando o processo de ensinar e aprender o cuidado domiciliar. Rev Bras Enferm [Internet]. 2018 Jan/Feb; [cited 2017 Dec 28]; 71(1):156-62. Available from: http://dx.doi.org/10.1590/0034-71672016-0541

10. Andrade AM. Aprendizagem reflexiva de enfermeiras na atenção domiciliar: caminhos para uma práxis criadora [Tese]. Belo Horizonte: Universidade Federal de Minas Gerais; 2017. 207 p.

11. Schön DA. Educando o profissional reflexivo: um novo design para o ensino e a aprendizagem. Porto Alegre: Artmed; 2000.

12. Sánches Vázquez A. Filosofia da práxis. $2^{\mathrm{a}}$ ed. São Paulo: Expressão Popular; 2011.

13. Yin RK. Estudo de caso: planejamento e métodos. Porto Alegre: Bookman; 2015.

14. Minayo MCS. O desafio do conhecimento: pesquisa qualitativa em saúde. 13를. ed. São Paulo: Hucitec; 2013.

15. Kock IV. A inter-ação pela linguagem. São Paulo: Contexto; 1997.

16. Fairclough N. Discurso e mudança social. Brasília: Editora Universidade de Brasília; 2001.

17. Godoy AS. Refletindo sobre critérios de qualidade da pesquisa qualitativa. Rev Eletr Gest Org [Internet]. 2005; 3(2):80-9. Available from: http://www.spell.org.br/documentos/ver/11383/refletindo-sobrecriterios-de-qualidade-da-pesquisa-qualitativa
18. Fairclough N. Discurso e mudança social. Brasília: UNB; 2008.

19. Ramalho V, Resende VM. Análise de discurso (para a) crítica: o texto como material de pesquisa. Campinas: Pontes; 2011.

20. Ministério da Saúde (BR). Conselho Nacional de Saúde. Resolução № 466, de 12 de dezembro de 2012. Diretrizes e normas regulamentadoras de pesquisas envolvendo seres humanos. Brasília (DF): Conselho Nacional de Saúde; 2012.

21. Lacerda MR, Zagonel IPS, Martins SK. Padrões do conhecimento de enfermagem e sua interface ao atendimento domiciliar à saúde. Online Braz J Nurs [Internet]. 2006; [cited 2018 Feb 10]; 5(2):1-9. Available from: http://www.objnursing.uff.br/index.php/nursing/rt/ printerFriendly/293/59

22. Carper B. Fundamental patterns of knowing in nursing. ANS Adv Nurs Sci [Internet]. 1978 Oct; 1(1):13-23. Available from: https://www.ncbi. $\mathrm{nlm}$.nih.gov/pubmed/?term=Fundamental+patterns+of+knowing+in+ nursing.+Advanced+Nursing+Science.+1978.+1(1)\%3A+13-23

23. Boufleur RN. Fundamentos da Gambiarra: a improvisação utilitária contemporânea e seu contexto socioeconômico [Tese]. São Paulo: FAU-USP;2013. 252 p. [cited 2017 Jun 28]. Available from: http://www. teses.usp.br/teses/disponiveis/16/16133/tde-02072013-134355/pt-br. php

24. Lima LSC, Souza NVDO, Gonçalves FGA, Pires AS, Ribeiro LV, Santos DM. Subjetividade dos trabalhadores de enfermagem e a prática de adaptar e improvisar materiais. Ciênc Cuid Saúde [Internet].2016. Oct/ Dec; [cited 2017 Jun 28]; 15(4):685-92. Available from: http://periodicos. uem.br/ojs/index.php/CiencCuidSaude/article/view/31555/18450

25. Santos DM. Adaptações e improvisos: repercussões para o processo de trabalho hospitalar da enfermagem [Mestrado]. Rio de Janeiro: Universidade do Estado do Rio de Janeiro; 2012. 164 p.

26. Souza NVDO, Santos DM, Anunciação CT, Thiengo PCS. O trabalho da enfermagem e a criatividade: adaptações e improvisações hospitalares. Rev Enferm UERJ (Rio de Janeiro) [Internet]. 2009 Jul/Sep; [cited 2017 Feb 15]; 17(3):356-61. Available from: http://www.facenf.uerj.br/v17n3/ v17n3a10.pdf

27. Arredondo-González CP, De La Cuesta-Benjumea C, Ávila-Olivares JA Heredar y Adaptar: la construcción de un mundo material tecnológico para los cuidados en salud en España (1855-1955). Texto Contexto Enferm [Internet]. 2016; 25(2):e2450014. Available from: http://www. scielo.br/pdf/tce/v25n2/es_0104-0707-tce-25-02-2450014.pdf

28. Cunha LS, Souza NVDO, Gonçalves FGA, Santos DM, Ribeiro LV, Pires AS. O trabalho hospitalar da enfermagem: dialética presente na prática de adaptar e improvisar. Rev Enferm UERJ (Rio de Janeiro) [Internet]. 2016; [cited 2017 Feb 15]; 24(5):e18835. Available from: http://www.e-publicacoes.uerj.br/index.php/enfermagemuerj/article/ viewFile/18835/20179

a Article extracted from the thesis "Reflective learning of nurses in home care: paths to reach a creative praxis" presented to the Graduation Course in Nursing, Escola de Enfermagem of the Universidade Federal de Minas Gerais (UFMG), in 2017. 